\title{
$5 \quad$ Influence of Pore Pressure at Tunnel face Einfluss des Porenwasserdrucks auf die Stabilität der Tunnelbrust
}

\section{A. Bezuijen}

GeoDelft, Delft, Niederlande

GeoDelft, Delft, The Netherlands

\begin{abstract}
The influence of groundwater flow in front of a tunnel face is investigated for a tunnel bored in saturated sand. It is shown that groundwater flow hampers the plastering of the bentonite slurry in front of a slurry shield. Consequences for the stability of the tunnel face for minimum and maximum face pressure are discussed. Groundwater flow increases the minimum allowable pressure and decreases the maximum allowable pressure and thus decreases the 'pressure window' that can be used by boring a tunnel.

Groundwater flow also has an influence during the grouting process for a tunnel drilled in sand. The consolidation of the grout, determines the pressures on the lining. Consolidation of grout is measured in an element test. Traditional calculation methods over predict the stresses on the lining for a tunnel drilled in stiff sand (up to a factor of 5 ) by not taking into account the consolidation of the grout.
\end{abstract}

KURZFASSUNG: Für den Bau eines Tunnels wurde der Einfluß der Grundwasserströmung auf die Stabilität der Tunnelbrust untersucht, der in gesättigtem Sand gebohrt wurde. Der Grundwasserzufluß hemmt die Filterkuchenbildung der Bentonitsuspension vor dem Hydroschild. Die Konsequenzen für die Stabilität der Tunnelbrust bei minimalem und maximalem Stützdruck werden beschrieben. Der Grundwasserzufluß erhöht den kleinsten zulässigen Stützdruck und verringert den größten zulässigen Stützdruck. Folglich wird der Bereich des anwendbaren Stützdruckes (das 'Stützdruckfenster') verringert, mit dem der Tunnel gebohrt werden kann.

Die Grundwasserströmung hat auch Einfluß während das Einbringen des Verpressmörtels. Die Konsolidation des Verpressmörtels bestimmt den Druck auf die Tunnelwandung. In einem Laborversuch wurde die Konsolidierung des Verpressmörtels getestet und gemessen. Traditionelle Berechnungsmethoden überschätzen die Spannungen auf die Wandung eines in steifem Sand gebohrten Tunnels (bis zum 5-fachen Wert), wenn die Konsolidationswirkung des Verpressmörtels nicht beachtet wird. 


\subsection{Introduction}

The soil is incorporated in the design of tunnels by calculating the soil pressures that are exerted on the tunnel and pressures necessary to have a stable tunnel face. Pore pressures are taken into account, but generally only a hydrostatic pressure distribution is assumed. However, the construction of a tunnel uses liquids pressurized with pressures different from the hydrostatic pressure: bentonite slurry at the tunnel face and grout mortar at the tail void. This will lead to excess pore pressures. Knowledge of these excess pore pressures appears to be of importance for the stability of the tunnel face and the final pressures on the lining.

This contribution describes the origin of the excess pore pressures in front of the tunnel face and also deals briefly with the influence of water flow in the grout mortar on the final pressures on a tunnellining.

\subsection{Pore pressures at the tunnel face}

\subsubsection{Background}

Shield tunneling started only recently in the Netherlands, the soft soil conditions and the high water table in most of the country are difficult conditions for this technique. The first tunnel bored was the $2^{\text {nd }}$ Heinenoord tunnel, just south of Rotterdam. To increase the knowledge of the processes involved when boring a tunnel in soft soil, a measurement campaign was set-up. Part of this campaign was measuring the pore pressures in front of the tunnel face.

\subsubsection{Measurements}

Pore pressure gauges (PPTs) were mounted in the tunnel track as a part of the measurement campaign. The total instrumentation, measuring deformations and pressures, in one of the measurement fields is shown in Figure 5.1. The PPTs in the tunnel track were in use until their destruction by the TBM. Results will be discussed for a PPT located in sand. Excess pore pressures were measured in front of the TBM during drilling. However, the pore pressure decreased until hydrostatic pressure when the drilling stopped.

The result of one of the gauges is shown in Figure 5.2. When the TBM reaches the PPTs, the passing of the cutters on the TBM can be seen in the measured pore pressures as variations in the pressure. The pressure decrease during a stand still can be seen in the 3-D plot, Figure 5.3, where the pressure is presented as a function of both the distance form the tunnel and the time. From this plot it is clear that when there is no progress in the drilling (the distance remains constant) the pressure decreases. The pressure starts to increase when drilling started en the distance between the gauge and the tunnel decreases.

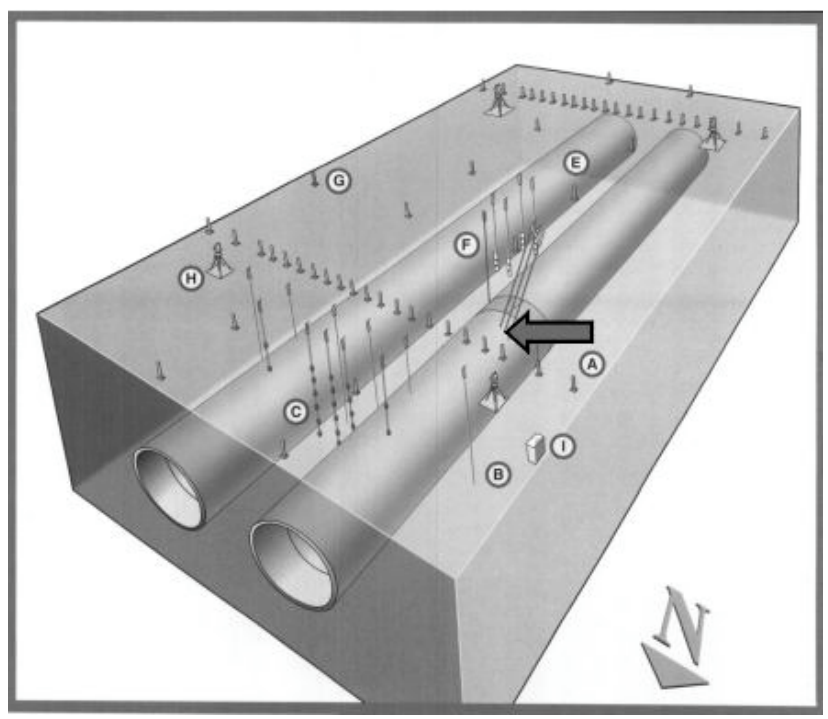

Figure 5.1: Artist impression measurement field. The arrow indicates the pore pressure gauges in front of the TBM. Results of the gauge in the middle are used this paper. /Bakker et al. 1999/

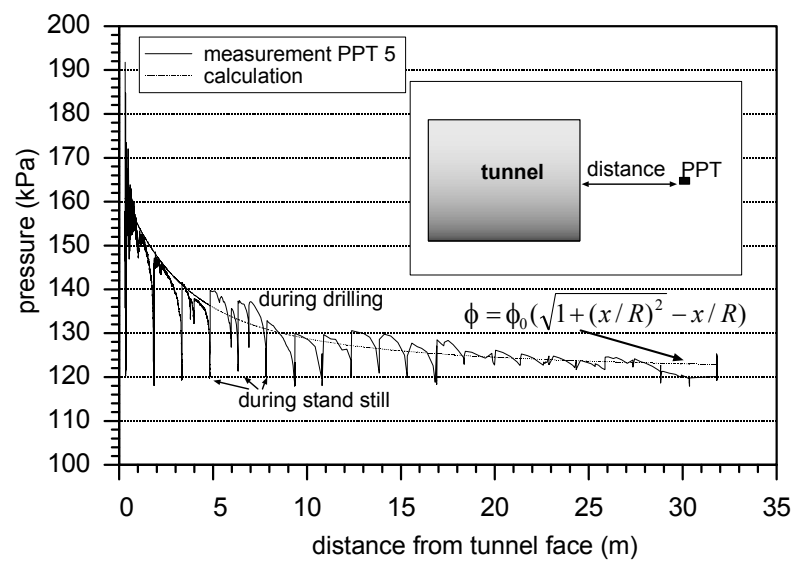

Figure 5.2: Measured excess pore pressure in front of a slurry shield and approximation

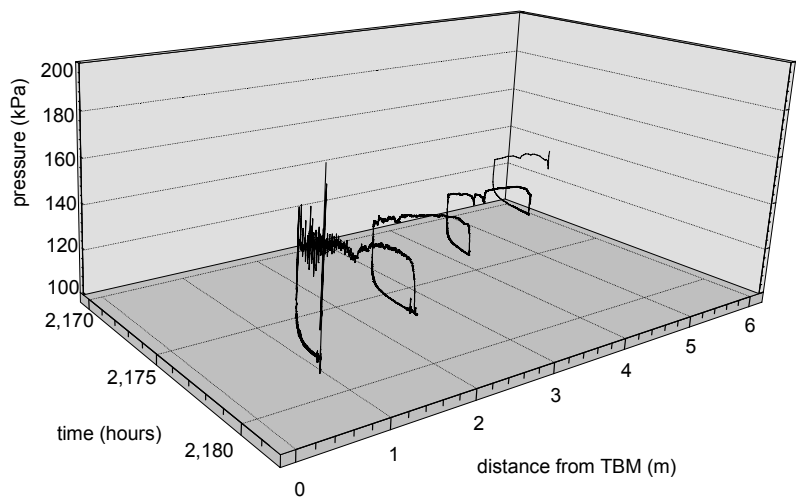

Figure 5.3: $3 D$ presentation of the measured excess pore pressure in front of a slurry shield

The measurements show that there is a plastering of the tunnel face by bentonite when drilling stops, but 
that there is no plastering during drilling. The reason for that will be explained in the next section.

\subsubsection{Pressure calculations}

If there is no plastering of the tunnel face at all, it is possible to calculate the excess pore pressure by means of groundwater flow computations. The actual 3D-boundary value problem reduces to a rather simple problem if we calculate the pressure in front of the tunnel at the tunnel axis, assuming a constant excess pore pressure over the tunnel face, a homogenous soil and no influence of the surface. For such a situation the solution of the piezometric head at the tunnel axis leads to:

$$
\phi=\phi_{0}\left(\sqrt{1+(x / R)^{2}}-x / R\right)
$$

Where $\phi$ is the excess piezometric head above the hydrostatic level at a distance $x$ from the tunnel face. $\phi_{0}$ the excess piezometric head at the tunnel face and $R$ the radius of the tunnel. This solution is plotted with the measurements in Figure 5.2 and showed good agreement.

With this solution it is also possible to understand why the bentonite at the tunnel face cannot provide plastering during drilling. The hydraulic gradient in front of the tunnel can be calculated by taking the derivative of Equation (5-1). At the tunnel face $(x=0)$ this leads to the equation with $i$ the hydraulic gradient. The pore water velocity (vp) in front of the tunnel can be written as::

$$
i=\phi_{0} / R
$$

with i the hydraulic gradient. The pore water velocity (vp) in front of the tunnel can be written as:

$$
v_{p}=\frac{k i}{n}
$$

where $k$ is the permeability of the sand an $n$ the porosity. When a tunnel with a diameter of $10 \mathrm{~m}(5 \mathrm{~m}$ radius) is drilled in sand with a permeability of $10^{-4}$ $\mathrm{m} / \mathrm{s}$ and a porosity of $40 \%$ (average values for this tunnel), the velocity of the pore water will be $2.5 \cdot 10^{-4}$ $\mathrm{m} / \mathrm{s}$. Bentonite cannot penetrate faster than the velocity of the pore water. If the drilling advances with $1 \mathrm{~mm} / \mathrm{s}$, this means that the drilling goes faster than the bentonite penetrates. Bentonite will penetrate, but every time a cutter of the rotor passes, it will take away all bentonite and there is no possibility to form a filter cake.

This means that the excess pore pressure measured is not caused because the bentonite does not plaster well enough. It is caused because drilling goes faster than bentonite penetration into the sand for this tunnel.

\subsubsection{Plastering}

When drilling stops, a filter cake will build up due to the mud spurt and consolidation of the bentonite slurry /Bezuijen 1997/. Using the results of experiments /Huisman 1998/ and the permeability of the soil, it is possible to derive the course of the pressure in the soil just in front of both the tunnel face and the slurry cake when drilling stops. At the axis close to the tunnel face there will be 1dimensional flow. In that situation the pressure, written as a piezometric head, in front of the tunnel due to the mud spurt (the most important mechanism) can be written as:

$\phi_{m s}=\frac{x \psi+n k_{w s} \phi_{0}+k_{s}\left(\phi_{0}-\Gamma x\right)}{x \psi+n k_{w s}+k_{s}}$

where $\phi_{\mathrm{ms}}$ is the piezometric head in the soil in front of the tunnel face, $\phi_{0}$ is the piezometric head at the tunnel face, $x$ the distance the bentonite has penetrated into the soil, $n$ the porosity, $k_{w s}$ the permeability of the consolidated slurry, $k_{s}$ the permeability of the soil for slurry, $\Gamma$ the ratio between applied piezometric head and final penetration of the bentonite slurry as measured in a plastering test, in which bentonite penetrates into a sand sample using a predefined pressure difference /Huisman 1998/. $\psi$ is the 1-dimensional flow resistance in the soil in front of the tunnel without bentonite (caused by groundwater flow only) and is defined as:

$q=\psi\left(\phi_{m s}-\phi_{\infty}\right)$

with $q$ the specific discharge and $\phi_{\infty}$ the piezometric head at a large distance from the tunnel ( $=0$ when the other values are presented as excess values). Since the thickness of the bentonite layer that penetrate into the soil during the mud spurt is very small compared to the dimensions of the tunnel, this layer can be neglected to determine $\psi$. Using equation (5-2) and Darcy's law q $=k \cdot i$ it is found:

$\psi=k / R$

$x$ in Equation (5-4) varies with time and is determined by the amount of slurry that has flown into the soil and can be solved using the equation:

$\frac{d x}{d t}=\frac{q}{n}=k_{s}\left(\frac{\phi_{0}-\phi_{m s}}{x}-\Gamma\right)$

To check the validity of these equations the results of PPT 5 measurements were used during the last drilling stop before the gauge was destroyed by the TBM. The result is shown in Figure 5.4 together with a the result of a calculation using the measured $\Gamma(133)$ and $\phi_{0}-\phi_{\infty}=3.5 \mathrm{~m}, \mathrm{n}=0.4, \quad \psi=2.5 \cdot 10^{-5} \quad 1 / \mathrm{s}$, $\mathrm{k}_{\mathrm{s}}=5 \cdot 10^{-5} \mathrm{~m} / \mathrm{s}$ and $\mathrm{k}_{\mathrm{ws}}=2.5 \cdot 10^{-8} \mathrm{~m} / \mathrm{s}$. The result showed reasonable agreement apart from pressure 
peaks that are present in the measured signal, probably because the rotor is still turning. Analysing laboratory results /Huisman 1998/ found that better agreement between measurements and calculations could be obtained if also the blocking of the pores by bentonite particles is taken into account by an empirical blocking factor. These field data do not clearly prove the need for such a factor.

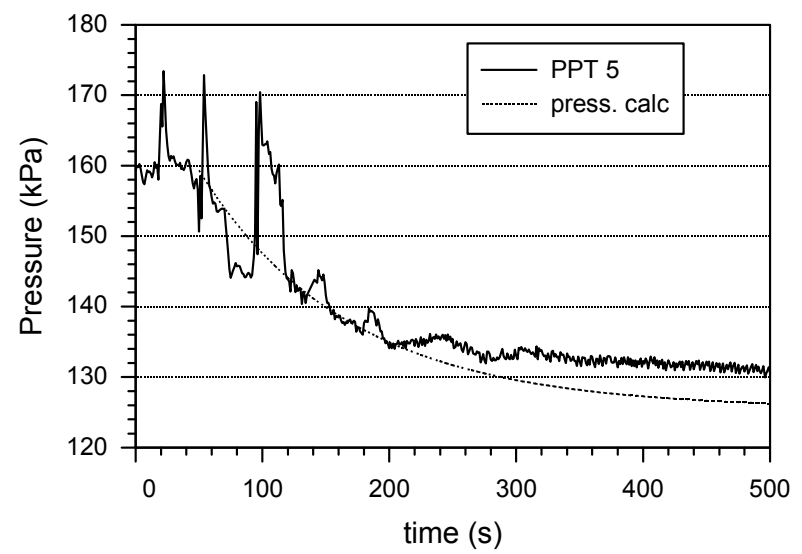

Figure 5.4: Measured and calculated pressure in the soil in front of a tunnel face during a stop in the drilling when a filter cake is built

\subsection{Consequences for stability}

Calculation methods for the stability of the tunnel face normally do not take into account the influence of excess pore pressure on the stability. It is generally assumed that the pressure at the tunnel face is directly applied to the grains, which means that implicitly a perfect plastering is assumed. Using the wedge shape failure mechanism as suggested by /Horn 1961/, /Anagnostou \& Kovári 1994/ and /Jancsecz \& Steiner 1994/, the influence of the excess pore water can be explained, see Figure 5.5. The figure shows a 3-dimensional plot of the failure surface and two 2-dimensional cross-sections. In the left 2-dimensional cross-section the situation as assumed in the various calculation methods is presented, the cross-section at the right presents the situation with excess pore pressures in the sand. Stability is obtained because the tunnel face pressure supports the triangle column ABCDEF.

It is clear that this support is less effective in the situation with excess pore pressure. As indicated in the figure, the net force to support the triangle is less. On the other hand, the excess pore pressure will also create a vertical gradient over the block CDEFGHIJ resulting in a reduction of the force from this block on the triangle.

To investigate the influence of the excess pore pressure on the stability, the analytical calculation methods as described by /Anagnostou \& Kovári 1994/ and /Jancsecz \& Steiner 1994/ has been adapted by /Broere 2000/ and as described in /CUR/COB 2000/. Both models showed comparable results, a significant increase in the minimum allowable tunnel face pressure to achieve a stable front.

Numerical calculations /Bezuijen et al. 2001/ have confirmed the results of these analytical calculations.

\subsection{Consequences for max. pressure}

The section above has dealt with the consequences for the face stability at minimum pressure. However, depending on the situation it is possible that the excess pore pressure influence the maximum allowable drilling pressure. An example of such a situation is discussed below.

In view of the excess pore pressures measured at the $2^{\text {nd }}$ Heinenoord tunnel it was decided to determine the possible risks of these excess pore pressures for another Dutch tunnelling project. The hypothesis that there might be a large risk involved arises from the geohydrological conditions in this polder area of Holland: relatively high piezometric levels compared to a low surface level. Calculations were made to check this in the design phase for a large tunnel project (14.9 $\mathrm{m}$ diameter) crossing a deep polder (Surface level $=\mathrm{SL}-5 \mathrm{~m}$; groundwater head average $=S L-3.5 \mathrm{~m}$, maximum $=S L-3 \mathrm{~m}$ ). The depth of the tunnel is shown in Figure 5.6. In the normal situation the weight of the (semi)confining top soil layer, consisting of only $7 \mathrm{~m}$ of peat and soft clay, just equals the upward forces from the groundwater underneath. A surplus of water pressure can disturb this vulnerable equilibrium state (bursting of the top layer).

The minimum slurry pressures, which are needed for a stable tunnel face during drilling were for this situation calculated using the analytical model of /Broere 2000/. As minimum excess pore pressure in front of the cake a value of $28.3 \mathrm{kPa}$ was determined (2.83 $\mathrm{m}$ surplus water head).

The slurry pressure can only be transmitted to the groundwater in the period that the slurry cake is cut from the soil face by the rotating cutting wheel of the TBM. As argued before, there will be no cake formation during drilling and drilling of one ring takes between 0.5 and 1.5 hours. However, the water pressure will not adapt directly to the slurry pressure during drilling due to the time dependent damping effect in the groundwater aquifer caused by the elastic storage capacity.

The groundwater effects just below the (semi)confining top were calculated with the finite difference groundwater program MODFLOW. The $10.5 \mathrm{~km}^{2}$ axial symmetrical model was multilayered (13 anisotropic model layers for the aquifer) and the input was: flow resistance top aquifer $c=10000$ days, total transmissivity aquifer $\mathrm{k}_{\mathrm{D}}=1600 \mathrm{~m}^{2} /$ day, storage capacity $S=1 \cdot 10^{-3}[-]$, anisotropy factor $k_{h} / k_{v}=3$. 


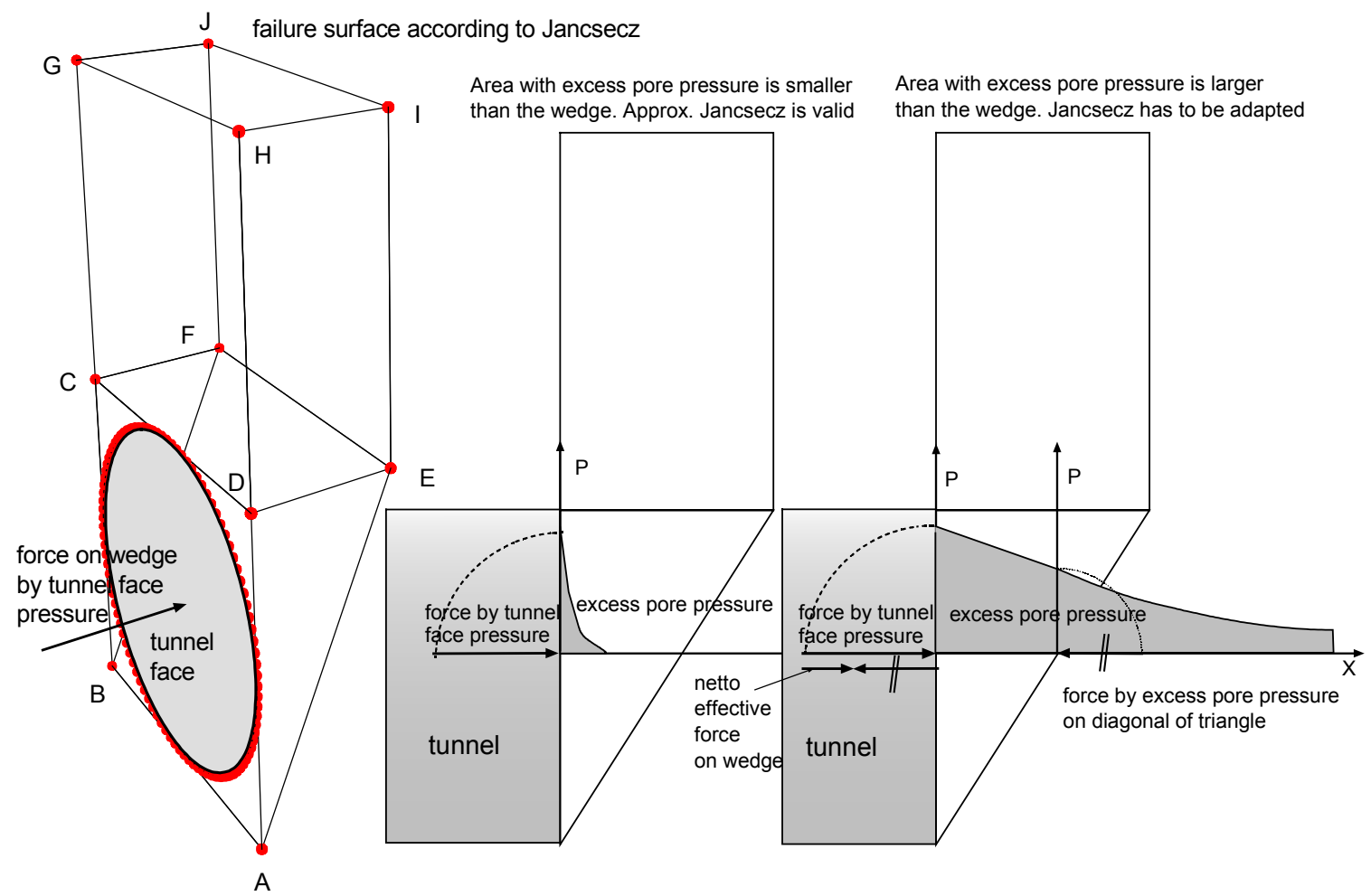

Figure 5.5: Sketch, influence of pore pressure on stability tunnel face. What is mentioned about the approach of Jancecz is also valid for the other "wedge shaped solutions" mentioned in the text

23.7

24.0

$24.3 \mathrm{~km}$

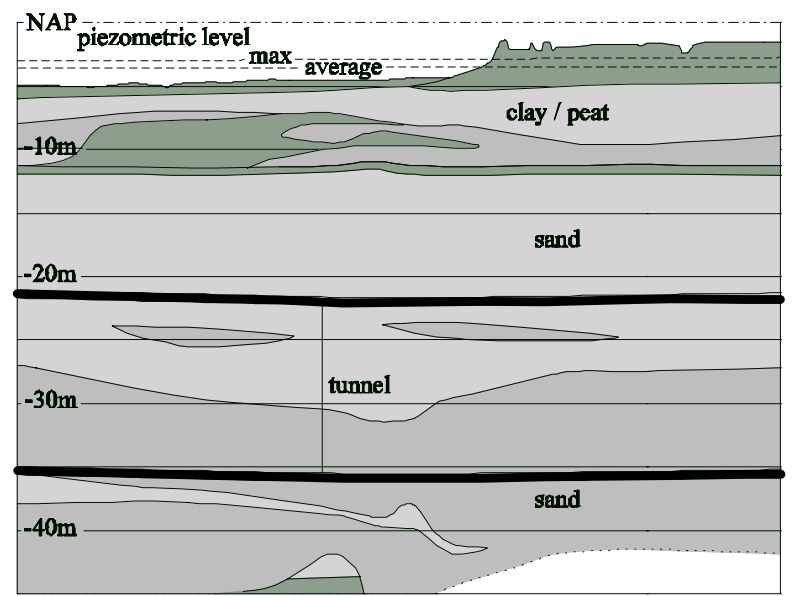

Figure 5.6: Geotechnical profile tunnel in polder

The calculated surplus water pressure depended on the duration of the drilling period as shown in Figure 5.7. The calculated extra water head below the confining layer is $1.05 \mathrm{~m}$. The calculation results led to the conclusion that the stated hypothesis concerning bursting risk is true. Measures to overcome problems, e.g. by monitoring and adaptation of the drilling procedure or even hydrological solutions must be considered in this situation.

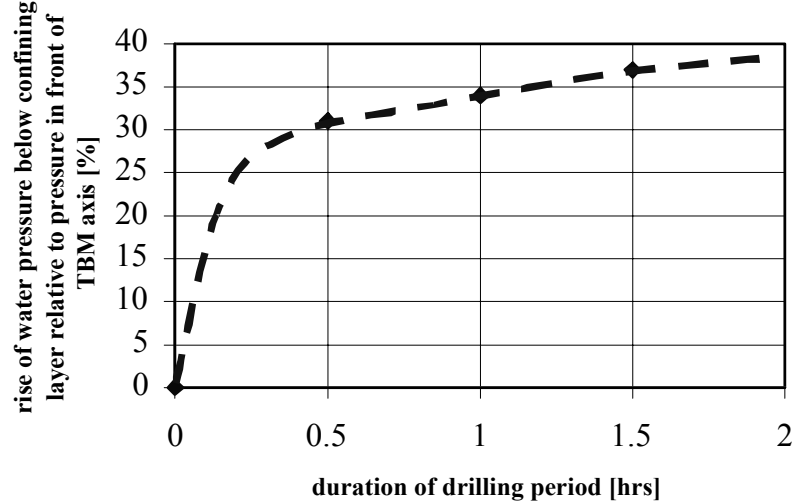

Figure 5.7: Calculated pressure build up when drilling starts

\subsection{Pore pressures and grouting}

\subsubsection{Description}

Grouting of the tail void is a critical process during the boring of a tunnel. It determines the loading on the lining of the tunnel and on the soil around the tunnel. Changing the grouting procedure can make the difference between a problematic and a successful project. Grout pressures to be applied are part of the regular design calculations for a tunnel project. Calculations are based on the stress distribution in the soil before the tunnelling starts, see for example Figure 5.8. 


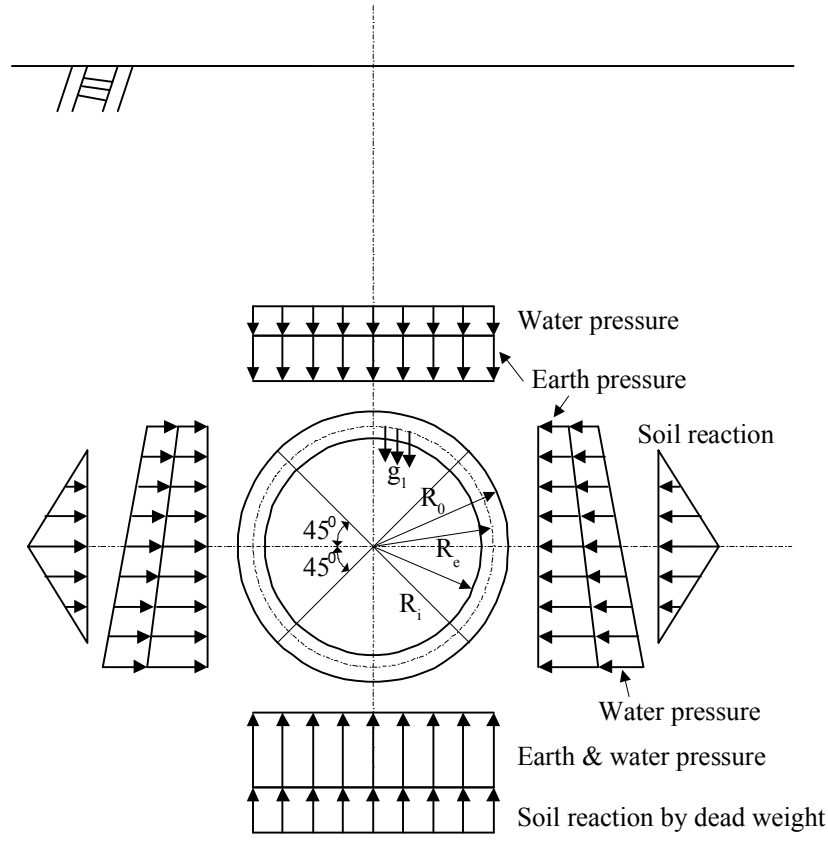

Figure 5.8: Conventional lining design method in Japan (from Hashimoto et al.2004)

However, it was found that for a tunnel in sand the measured pressures around the lining at some rings from the TBM are close to the pore pressure /Bezuijen et al. 2003/ and furthermore that the measured loading on the tunnel in sand is much lower than calculated, see Figure 5.9/Hashimoto et al. 2004/.

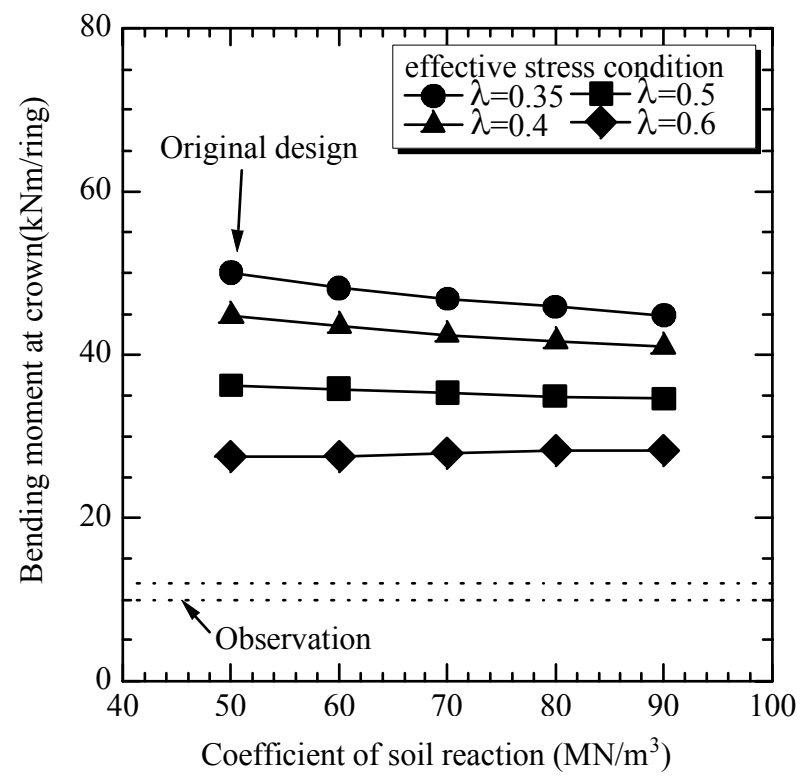

Figure 5.9: Discrepancy between design and calculation. The point to which the arrow points is the original design for a tunnel in sand. Changing of parameters does not result in a better fit

To understand this behaviour it is necessary to look more into detail into the properties of the grout mortar. This mortar is injected as a liquid. As long as it is a liquid there will be no direct interaction between de soil and the tunnel lining. The average grout pressure will be determined by the pore pressure plus the grain stresses and the pressure distribution in the grout by the properties of the grout and the weight of the lining /Bezuijen et al. 2004/.

Due to the excess pore pressure in the grout it will consolidate and looses its water to the soil around the tunnel. The speed of consolidation depends on the permeability of the grout in case the tunnel is bored in sand but on the permeability of the subsoil for a tunnel bored in less permeable subsoil as clay. This consolidation leads to a volume reduction of the grout and therefore also to a reduction of the effective stresses in the soil. A sandy soil will react very stiff to unloading and therefore a small reduction of the grout volume (a reduction of 5 to $10 \%$ of the grout volume was measured in consolidation tests), leads to a considerable reduction of the effective stresses in the sand and thus also to a reduction of the loading on the tunnel.

\subsubsection{Measurements}

\subsubsection{Laboratory measurements}

It is difficult to measure the consolidation of grout in a traditional oedometer test, because the consolidation is fast compared to the consolidation of clay or peat. Furthermore it is possible that there will be hardening of the grout during the consolidation process. Therefore consolidation experiments were performed in a cylindrical cell with a diameter of 0.3 $\mathrm{m}$ in which a grout layer was made of $0.2 \mathrm{~m}$, comparable to the average thickness of a grout layer in the tail void for tunnels with diameters in the range of 6 to $11 \mathrm{~m}$.

The test set-up is shown in Figure 5.10 and Figure 5.11. The grout sample is loaded with air pressure to the desired pressure. The test measures the consolidation properties of the grout assuming relatively permeable subsoil and consolidation in one direction (water can flow into the soil not to the lining of the tunnel). The flow resistance of the sand is much lower than that of the grout. After several minutes of consolidation the sample was unloaded and the shear strength of the grout was measured at different locations in the grout.

An example of results of such a test is shown in Figure 5.12 and Figure 5.13. Figure 5.12 shows the amount of expelled pore water as a function of time and the applied pressure. In this test a pressure of $300 \mathrm{kPa}$ was applied. Pressure was relieved several times to be able to take the vane tests. Figure 5.13 shows the measured shear strength as a function of depth after for different times of applied pressure. In this test it was focussed on the lower values of the shear strength. Therefore only shear strengths up to $6 \mathrm{kPa}$ were measured and presented in the plot.

The type of grout tested here was tested before at atmospheric pressure /Bezuijen et al. 2002/. In that test it appeared that the measured shear strength remained more or less constant until 5.5 hours and after that time the hardening of the grout started. 


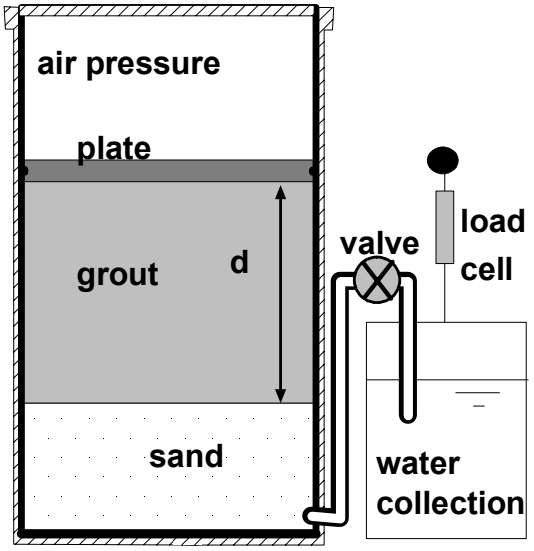

Figure 5.10: Measurement principle

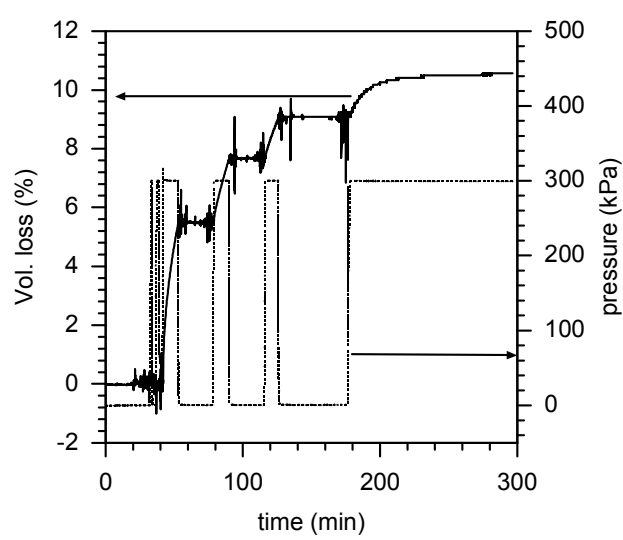

Figure 5.12: Test result: volume loss as a function of time and applied pressure

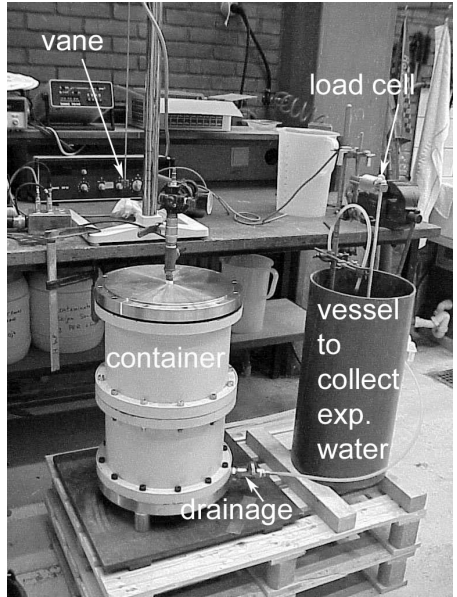

Figure 5.11: Experimental setup

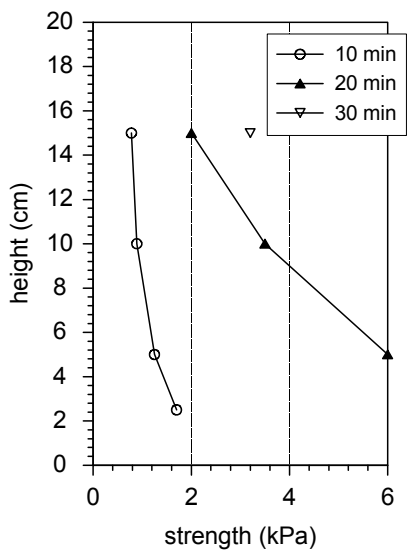

Figure 5.13: Strength development as measured with a vane
Comparing the result from the test at atmospheric pressure with the results of the tests at 1 - 3 bar over pressure it became clear that the increase in strength in the over pressure case is caused by consolidation of the grout and not by the hardening of the grout. To understand the grout properties just after injection in the tail void it is therefore necessary to understand consolidation. If the grout layer is consolidated, it will have certain strength to act as a foundation for the tunnel lining, even before hardening of the grout commences. If it is not consolidated it is possible that the shear strength is too low to counterbalance the buoyancy forces of the tunnel. Another important consequence of consolidation is an increase of flow resistance, which directly affects the pressure distribution behind the TBM when drilling.

Consolidation of grout, sometimes called bleeding, cannot be described by linear consolidation theory. It can be approximated assuming it behaves as a grain-water mixture with little strength until the water is expelled from the grout and there is an effective stress between the grains. A description is presented in /Bezuijen \& Talmon 2003/.

\subsubsection{Field tests}

Grout pressures during injection and after injection were measured during tunnel projects in the
Netherlands. Characteristic results are shown in Figure 5.14.

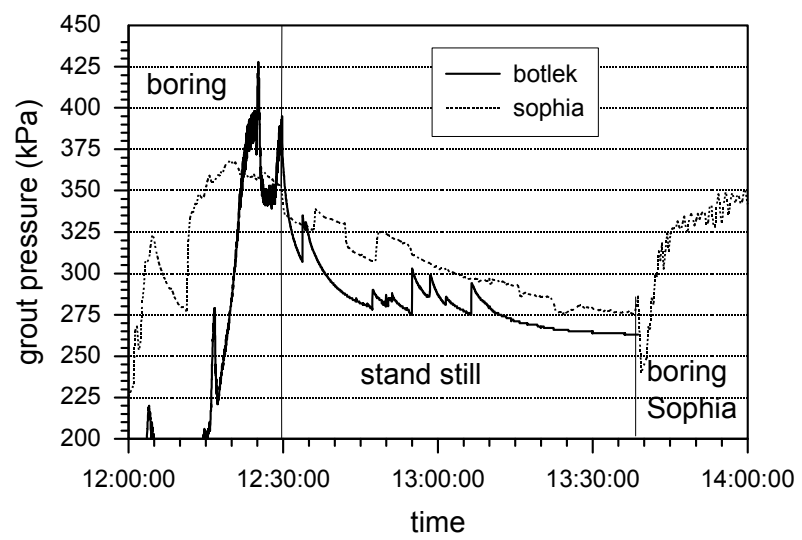

Figure 5.14: Grout pressure measured at the Botlek Rail tunnel and the Sophia Rail Tunnel. Data is shifted so that drilling stops at the same point (first ring after the instruments came out of the lining)

The grout pressure increases during drilling and decreases to values that are close to the pore pressure of water during stand still due to consolidation of the grout and decrease of the effective stress due to unloading of the soil. The pressure distribution around the tunnel, measured on the lining appears to increase linearly with depth. 
However it is not a hydrostatic pressure distribution, see Figure 5.15. The gradient varies in time and decreases to values below the gradient of the pore water. This is caused by buoyancy forces exerted by the lining and the yield stress in the grout/Bezuijen et al. 2004/.

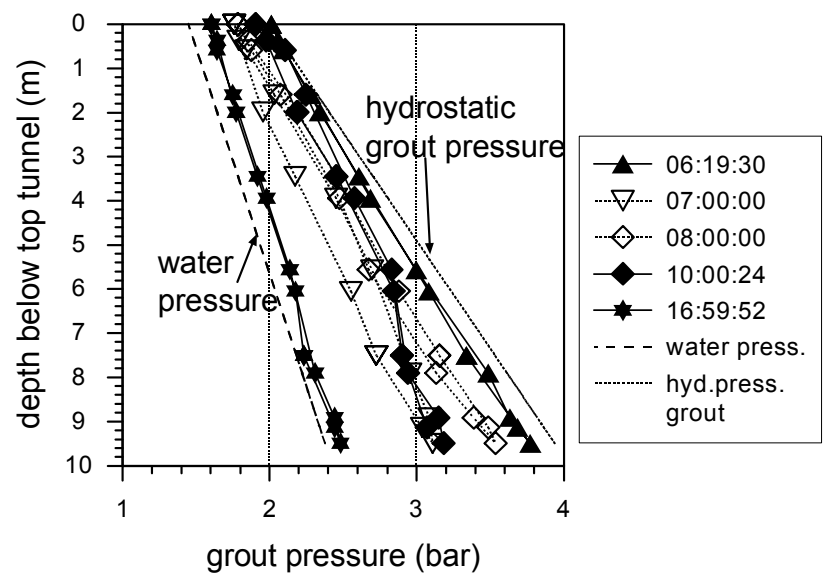

Figure 5.15: Measured grout pressure distribution at the Sophia Rail tunnel at various times. The pressure measured at 16:59:52 was measured several hours after boring has stopped

\subsection{Conclusions}

It is shown that the measured excess pore water pressures in front of the tunnel face are mainly caused by the groundwater flow conditions much less influenced by the slurry properties. During stand still plastering occurs. The formulation for this plastering, presented in this paper, presents reasonable results, but needs the input of plastering experiments. The excess pore pressures during drilling have consequences for as well the minimum and maximum pressures that can be allowed at the tunnel face.

The average pressure on the lining due to grouting reduces to values close to the pore pressure several rings after the TBM for a tunnel made in sand. This is caused by the volume loss due to consolidation in the grout. The pressure gradient around the tunnel is determined by the buoyancy forces in the lining. Due to these mechanisms the resulting stress distribution around the lining can differ considerably from the results of traditional calculations. More in general it can be said that ground water flow and the resulting pore pressures needs attention when drilling a tunnel below the water table.

\section{Acknowledgment:}

HSL-Noord, COB, Delft Cluster.

\subsection{References}

Anagnostou, G. \& Kovári, K. 1994

The face stability of Slurry-shield-driven Tunnels, Tunelling and Underground Space Technology, Vol 9. No.2., pp. 165-174
Bakker, K.J.; de Boer, F.; Kuiper, J.C. 1999

Extensive independent research programs on $2^{\text {nd }}$ Heinenoord tunnel and Botlek Rail tunnel, Proc. XII ECSMGE, Amsterdam

Bezuijen, A. 1997

Plastering and mud spurt during drilling (in Dutch), BTL-report 27

Bezuijen, A.; Pruiksma, J.P.; van Meerten, H.H. 2001

Pore pressures in front of tunnel, measurements, calculations and consequences for stability of tunnel face, Proc. Int. Symp. on Modern Tunneling Science and Techn., Kyoto

Bezuijen, A. \& Talmon, A.M. 2003

Grout the foundation of a bored tunnel, 2003, Proc. ICOF 2003, Dundee

\section{Bezuijen, A. \& Talmon, A.M. 2004}

Grout pressures around a tunnel lining, influence of grout consolidation and loading on lining, Proc. ITA 2004, Singapore

Bezuijen, A.; Talmon, A.M.; Kaalberg, F.J.; Plugge, R. 2004

Field measurements on grout pressures during tunnelling, Soils and Foundations

Broere, W.; van Tol, A.F. 2000

Influence of infiltration and froundwater flow on Tunnel stability, Proc. Int. Conf. on geotechnical aspects of underground construction in soft grounds, eds. Kusakabe O.; Fujita, K.; Niyazaki, Y.

\section{CUR/COB 2000}

Directive for the design of drilled tunnels for roads and tunnels, final report commission L500 (in Dutch)

Hashimoto, T.; Brinkman, J.; Konda, T.; Kano, Y.; Feddema, A. 2004

Simultaneous Backfill Grouting, Pressure Development in Construction Phase and in the Long-Term, Proc. ITA 2004, Singapore

Horn, N. 1961

Horizontaler Erddruck auf senkrechte Abschlussflächen von Tunnelröhren, Landeskonferenz der Ungarischen Tiefbauindustrie, pp. 7-16

Huisman, M. 1998

Static plastering, Theory and experiments, BTLreport 34, WL | Delft Hydraulics J1384 (in Dutch)

Jancsecz, S. \& Steiner, W. 1994

Face support for a large Mix-shield in heterogeneous ground condtiontions, Tunneling '94, pp. 531-550 